\title{
SISTEM INFORMASI PEMILIHAN ASISTEN LABORATORIUM DENGAN METODE WEIGHTED PRODUCT DAN WEIGHTED SUM MODEL
}

\author{
Nur Hayati ${ }^{1}$, Sri Rahayu ${ }^{2}$, Tri Ichsan Saputra ${ }^{3}$ \\ Informatika, Universitas Nasional ${ }^{1,2,3}$ \\ nurh4y@gmail.com
}

Submitted January 1, 2021; Revised July 4, 2021; Accepted July 5, 2021

\begin{abstract}
Abstrak
Proses pemilihan asisten pada sebuah fakultas pada umumnya didasarkan pada persyaratanpersyaratan seperti IPK, tahun angkatan dan bahkan ada yang diterima secara subjektif karena penilaian langsung dari seorang dosen yang merangkap sebagai seorang kepala laboratorium. Bentuk pemilihan yang seperti itu memang tidak bermasalah selama memang mahasiswa tersebut layak untuk menjadi seorang asisten. Akan tetapi dokumentasi dari sistem penerimaan yang seperti itu seringkali tidak berjejak. Oleh karena itu, aplikasi untuk proses pemilihan asisten sangat diperlukan untuk membuat proses lebih terdokumentasi dan bersifat objektif. Berdasarkan syarat-syarat penerimaan asisten yang sebelumnya sudah dilaksanakan, maka metode sistem pendukung keputusan Weighted Product dapat digunakan dalam proses pembobotan karena lebih spesifik ke bobot-bobot nilai disetiap kriterianya dan Weighted Sum Model dapat digunakan untuk proses perangkingan sehingga hasil keputusannya bisa tepat, cepat dan bersifat objektif. Hasil penelitian didapat $100 \%$ keberhasilan pengujian dari sisi interface dan hasil penelitian berupa sistem informasi pemilihan asisten laboratorium berbasis website yang didasarkan pada kriteria nilai IPK, nilai mata kuliah praktikum, nilai mata kuliah kekhususan dan nilai soal.
\end{abstract}

Kata Kunci : Sistem Pendukung Keputusan, Weighted Product, Weighted Sum Model, Sistem Informasi, Kriteria

\begin{abstract}
The process of selecting assistants at a faculty is generally based on requirements such as GPA, year of class, even some are accepted subjectively because of the direct assessment of a lecturer who is also the head of the laboratory. This form of election isn't problematic as long as the student is indeed worthy of being an assistant. However, the documentation of such an admissions system is often not traceable. Therefore, an application for the assistant selection process is indispensable to make the process more documented and objective. Based on the conditions for accepting assistants that have previously been implemented, the Weighted Product decision support system method can be used in the weighting process because it is more specific to the value weights in each criterion and the Weighted Sum Model can be used for the ranking process so that the decision results can be precise, fast and objective. The results obtained were 100\% test from the interface side and then the results of the study were in the form of a website-based information system for selecting laboratory assistants based on the criteria for GPA, practical course scores, specificity course scores and question scores.
\end{abstract}

Key Words : Decision Support Systems, Weighted Products, Weighted Sum Models, Information Systems, Criteria

\section{PENDAHULUAN}

Rekrutmen asisten praktikum laboratorium di Fakultas Teknologi Komunikasi dan
Informatika dilakukan sesuai dengan kebutuhan secara manual dengan alur setiap mahasiswa yang akan mencalonkan 
diri menjadi asisten laboratorium harus melakukan proses pendaftaran di laboratorium dengan membawa berkas untuk melengkapi persyaratan yang telah ditentukan. Persyaratan untuk proses penerimaan asisten laboratorium terdiri dari beberapa kriteria penilaian yaitu a. Nilai Indeks Prestasi Komulatif, b. Nilai Mata kuliah yang berelevansi dengan Kegiatan Praktikum yang dilaksanakan di Laboratorium, c. Surat Lamaran Asisten dengan batasan waktu pendaftaran yang telah ditentukan untuk selanjutnya dilakukan proses seleksi pemilihan asisten.

Proses pemilihan Asisten dilakukan oleh Kepala Laboratorium dengan perhitungan bobot kriteria yang telah ditetapkan setelah waktu pendaftaran ditutup. Pada proses pengambilan keputusannya dinilai masih bersifat subjektif dan kurang optimal karna proses pemilihan yang cukup panjang dan lama yaitu 1-2 Minggu hingga bisa diputuskan siapa yang terpilih, maka dari itu perlu dibuatkan sebuah sistem penunjang keputusan pemilihan asisten sehingga dapat mempersingkat waktu dan proses.

Pada penelitian ini penulis menggunakan metode Weighted Product dalam proses pembobotannya, karena metode ini dinilai lebih spesifik langsung kepada bobotbobot nilai di setiap kriterianya, sedangkan untuk proses perankingan digunakan metode Weighted Sum Model yang diharapkan mampu memberikan hasil keputusan yang tepat dan cepat serta bersifat objektif.

\section{METODE PENELITIAN}

\section{Metode Weighted Product}

Metode WP merupakan salah satu dari beberapa metode MADM (Multi Atribute Decision Making). Metode MADM merupakan metode pengambilan keputusan yang didasarkan pada beberapa atribut. Konsep permasalahannya adalah mengevaluasi $\mathrm{m}$ alternatif $\mathrm{Ai}(\mathrm{i}=1,2, \ldots, \mathrm{m})$ terhadap sekumpulan atribut atau kriteria $\mathrm{Cj}(\mathrm{j}=1,2, \ldots, n)$, dimana setiap atribut tidak saling bergantung satu dengan yang lainnya [1]. Metode ini mengharuskan pembuat keputusan menentukan bobot bagi setiap atribut.

Metode WP menggunakan proses normalisasi, dimana rating setiap atribut harus dipangkatkan dahulu dengan bobot atribut yang bersangkutan. Proses ini diberikan dengan rumus sebagai berikut [2]:

$$
s_{i}=\prod_{j=1}^{n}=x_{i j}{ }^{w i j}
$$

dengan $i=1,2, \ldots, m$, dimana:

$\mathrm{S}$ : Menyatakan preferensi alternatif,

$\mathrm{x}$ : Menyatakan nilai kriteria,

w: Menyatakan bobot kriteria,

$\mathrm{n}$ : Menyatakan banyaknya kriteria.

wij adalah pangkat bernilai positif untuk atribut keuntungan, dan bernilai negatif untuk atribut biaya. Metode Weight Product dalam perhitungannya lebih singkat yaitu terdiri dari 3 langkah [3]. Langkah-langkahnya sebagai berikut:

1) Perbaikan bobot kriteria

2) Menghitung vektor S. langkah ini sama seperti proses normalisasi

3) Menghitung vektor $V$, atau preferensi relatif dari setiap alternatif.

\section{Weighted Sum Model}

Weighted Sum Model (WSM) adalah model umum, telah digunakan untuk aplikasi yang berbeda seperti robotika, processor, dan lain-lain. Ini adalah metode yang sering digunakan pada permasalahan dimensi tunggal. Jika terdapat $m$ alternatif dan $n$ kriteria, maka alternatif terbaik dapat dirumuskan sebagai berikut [4]:

$$
\begin{aligned}
& A i^{\text {WSM-Scrore }} \\
& =\sum_{J=1}^{n} w_{j} a_{i j}, \text { for } i \\
& =1,2,3, \ldots ., \mathrm{m} .
\end{aligned}
$$


Dimana $\mathrm{i}=1,2,3, \ldots, \mathrm{m}$ dan merupakan nilai dari alternatif terbaik $\mathrm{n}$ adalah banyaknya kriteria merupakan nilai alternatif i pada kriteria $\mathrm{j}$ adalah nilai bobot kriteria $\mathrm{j}$ dan max digunakan untuk mengurutkan alternatif keputusan dimana alternatif yang memiliki nilai terbesar akan diletakkan dipaling atas. Kesulitan pada metode ini hadir ketika yang digunakan bukanlah kriteria dimensi tunggal atau multi dimensi. Dalam permasalahan tersebut, maka kriteria yang ada harus disamakan menjadi satu dimensi yang sama [5].

\section{Perangkat Penunjang}

Perangkat-perangkat yang penulis gunakan selama proses penyelesaian Sistem Aplikasi Pemilihan ini dibagi menjadi dua kategori,adalah sebagai berikut [6]:

1) Perangkat Keras (Hardware)

Berdasarkan kebutuhan sistem yang akan dibangun ini berbasis web, maka dapat dipastikan bahwa perangkat keras yang dibutuhkan harus mendukung kebutuhan dan mampu terkoneksi ke jaringan internet. Adapun perangkat keras yang penulis gunakan ialah satu buah Laptop dengan spesifikasi yaitu processor Intel® Core i3, CPU 1,9 GHz, Windows 10 64-bit, HDD 500 GB dan NVIDIA GeForce 820M.

2) Perangkat Lunak (Software)

Dalam proses penyelesaian sistem ini penulis menggunakan beberapa perangkat lunak, baik untuk perancangan sistem, desain layout, pembangunan database, serta pembangunan sistem, diantaranya adalah sebagai berikut:
a. Microsoft Visio 2010
b. Adobe Photoshop CS3
c. PHP Versi 5.6.12
d. Framework Codeigniter 3.1
e. MySql 5
f. Virtual Webserver (XAMPP)
g. Text Editor (SublimText)
h. Browser (Mozila,Chrome,Opera)

\section{HASIL DAN PEMBAHASAN}

\section{Analisis}

Proses pendaftaran asisten laboratorium selama ini dilaksanakan di awal semester dengan jumlah asisten yang diterima berdasarkan kebutuhan. Adapun alur proses yang berjalan selama ini adalah seperti yang di jelaskan pada Error! Reference source not found.. dimulai dengan pihak laboratorium menyebarkan pamlet pengumuman penerimaan untuk calon asisten dengan persyaratan yang telah di tentukan dengan batasan waktu pendaftaran yang ditentukan, yaitu sekitar 2 minggu [7]. Hal tersebut ditunjukan untuk para calon asisten dapat mempersiapkan dan mengumpulkan data atau berkas untuk melengkapi persyaratan yang ada.

Tahapan selanjutnya ialah proses pemilihan yang dilakukan oleh Kepala Laboratorium dengan menggunakan perhitungan nilai bobot pada masingmasing persyaratan, sehingga didapatkan rangking dari setiap calon yang kemudian dinyatakan diterima sebagai Asisten Laboratorium [8].

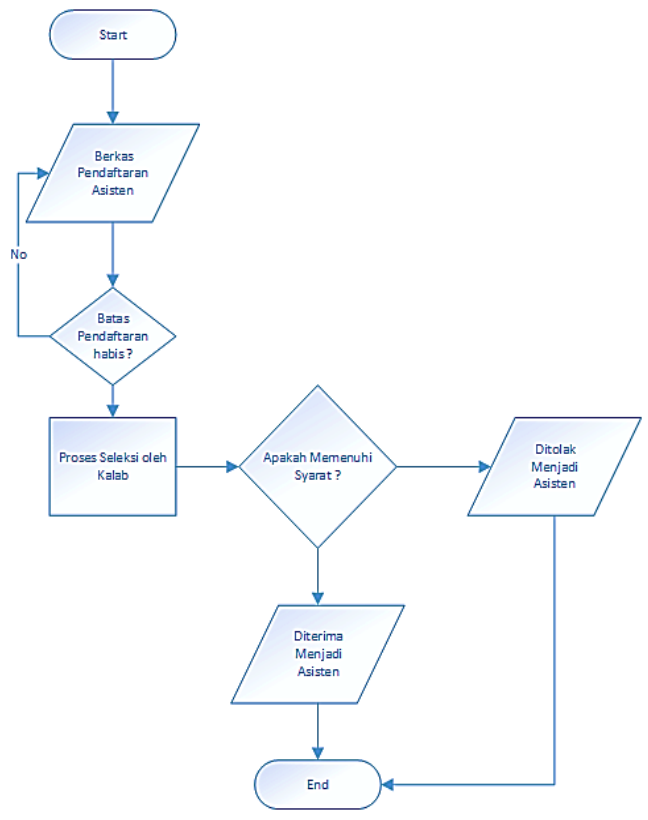

Gambar 1. Flowchart Proses Pemilihan Asisten Laboratorium Geofisika 


\section{Rancangan Sistem}

Pada proses perancangan sistem yang akan dibangun, penulis menggunakan pemodelan UML (Unified Modelling Language) yang terdiri dari tiga (3) diagram, adapun diagram yang digunakan adalah sebagai berikut:

\section{1) Use Case Diagram}

Pada pembuatan Use Case Diagram hal pertama yang dilakukan adalah menentukan actor atau pengguna, pada sistem ini terbagi menjadi empat (4) actor yaitu Mahasiswa, Publik Umum, Kepala Laboratorium dan Administrator Laboratorium [9].

Setelah melakukan penentuan actor maka tahap selanjutnya adalah menentukan Use Case Requitment atau aktifitas yang diberikan untuk actor, dan memberikan interaksi antar actor terhadap Use Case yang didefinisikan melalui pembuatan Use Case Diagram.

Pada Use Case Diagram ini terbagi menjadi dua bagian utama yaitu bagian frontend dengan dua actor mahasiswa dan publik umum, dan bagian back end dengan dua actor yaitu administrator dan kepala laboratorium yang mewajibkan untuk melewati proses login terlebih dahulu, setelah login admin dan kalab masing masing memiliki akses tertentu, sedangkan untuk halaman front end tidak memerlukan proses login terlebih dahulu antuk mengaksesnya. Gambar Use Case Diagram sistem ini dapat dilihat pada Error! Reference source not found.

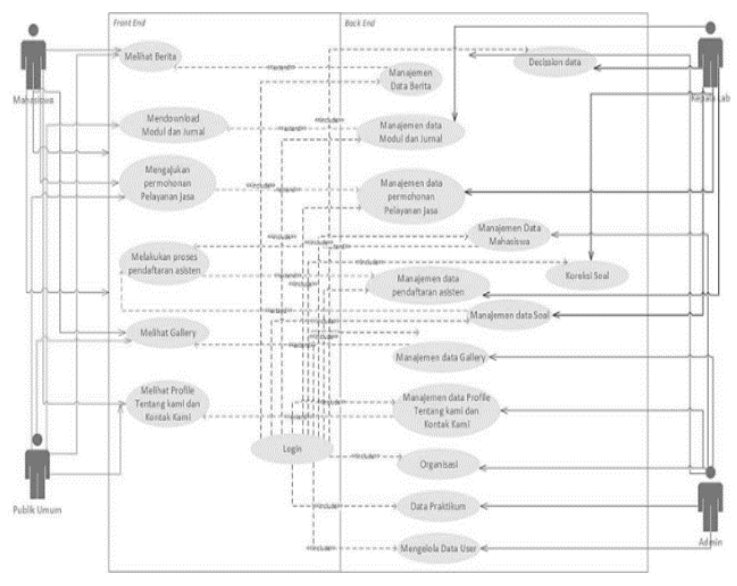

Gambar 2. Use Case Diagram

\section{2) Activity Diagram}

Activity Diagram merupakan diagram untuk menggambarkan logika prosedur, proses bisnis, dan jalur kerja [11]. Sistem Penunjang Keputusan Pemilihan Asisten Laboratorium ini dapat dibagi empat (4) bagian Activity Diagram yang di tunjukan oleh Error! Reference source not found. dan Error! Reference source not found. Activity Diagram sebagai publik tidak membutuhkan login terlebih dahulu untuk mengakses berbagai informasi yang ada pada website, begitupun untuk akses sebagai Mahasiswa, namun terdapat perbedaan diantara keduanya yaitu untuk laman "Pendaftaran Asisten" yang hanya dapat diakses oleh mahasiswa karena membutuhkan verifikasi sebagai mahasiswa Program Studi Teknik Geologi.

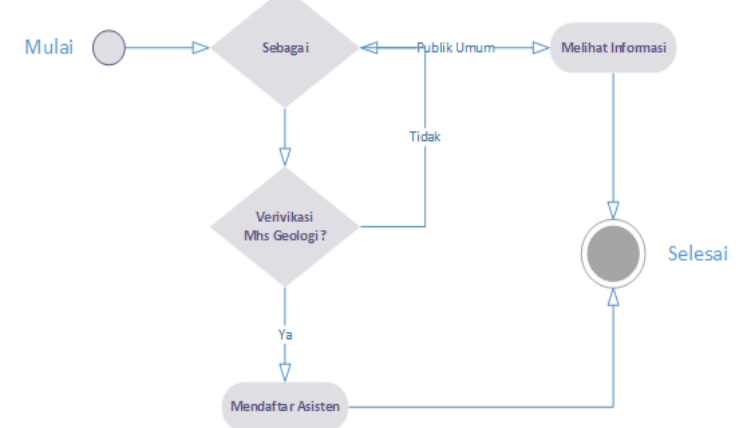

Gambar 3. Activity Diagram Sebagai Mahasiswa dan Publik Umum

Activity Diagram sebagai kepala laboratorium dan administrator laboratorium dibedakan dengan memiliki 
hak akses masing-masing yang harus

\section{Rancangan Database}

melewati proses login terlebih dahulu, dan diakhiri dengan proses logout.

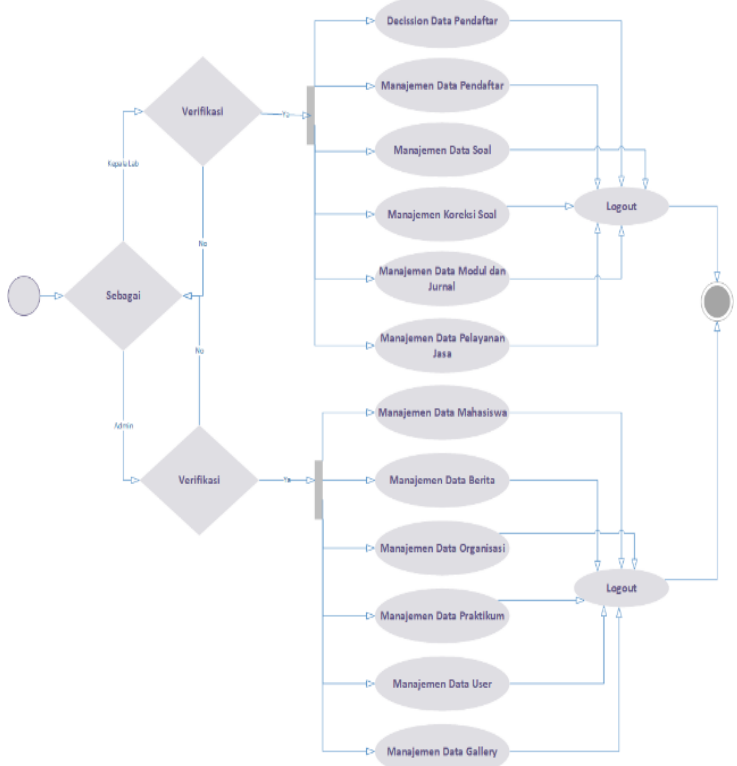

Gambar 4. Activity Diagram Sebagai

Kepala Laboratorium dan Admin

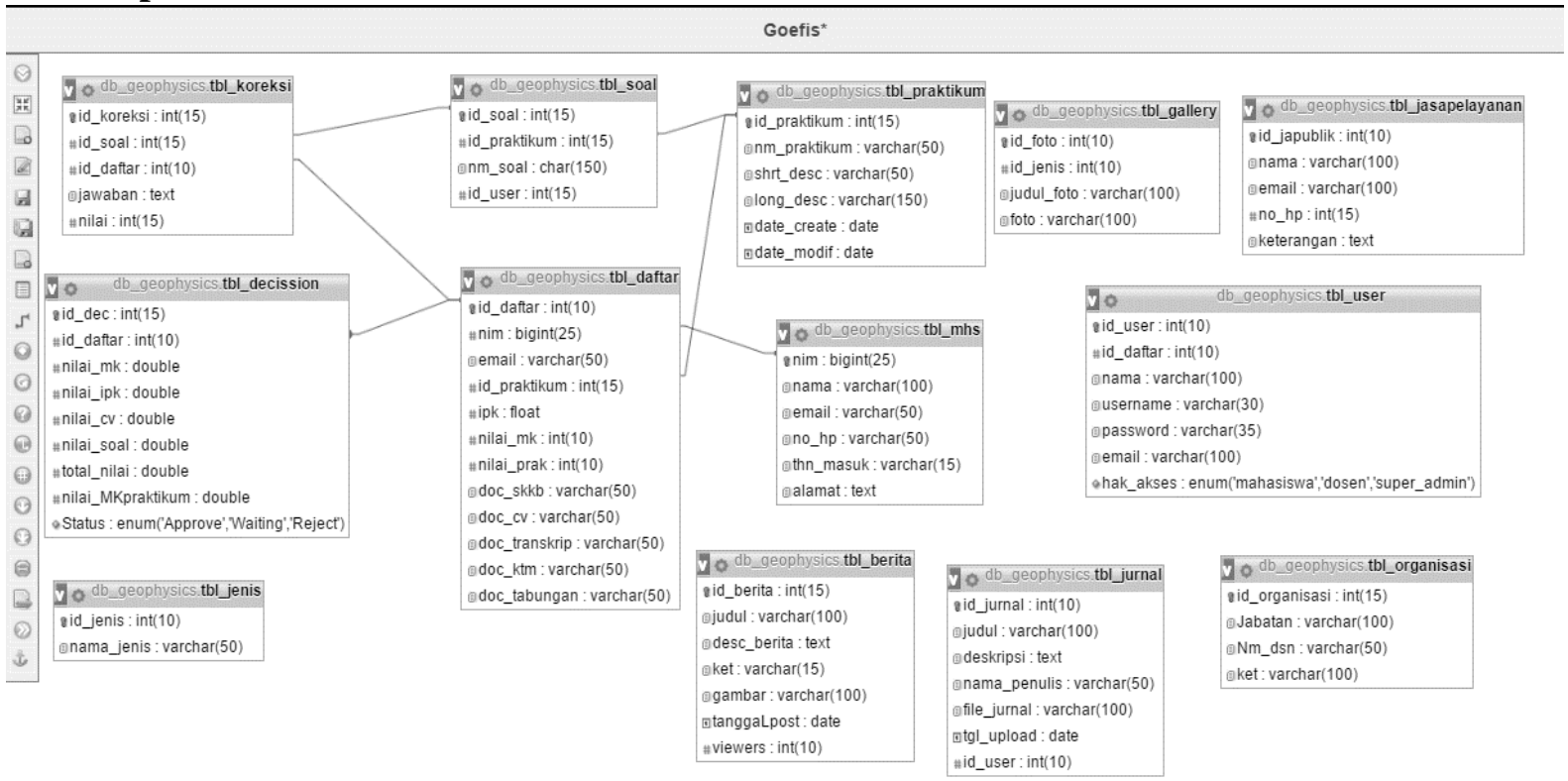

\section{Gambar 5. Relasi Database}

Database merupakan sekumpulan data yang saling terhubung sehingga dapat menghasilkan sebuah informasi yang berguna dalam proses pembuatan sebuah sistem [10]. Dalam proses pembuatan sistem ini penulis merancang database dengan menggunakan 13 tabel data dan direlasikan antar tabel seperti yang tergambar pada Error! Reference source not found.. Tabel Daftar berelasi dengan tabel mahasiswa, tabel decision, tabel koreksi berelasi dengan tabel daftar begitupun tabel koreksi yang berrelasi juga dengan tabel soal, dan tabel soal yang berelasi dengan tabel praktikum [11]. 


\section{Implementasi Sistem}

1) Halaman Homepage

Halaman homepage adalah halaman yang pertama kali muncul ketika membuka alamat website Laboratorium FTKI. Pada halaman homepage terdapat informasi yang disajikan untuk user diantaranya adalah: Portal berita mengenai kegiatankegiatan di lingkungan Laboratorium, yang dikategorikan dalam Jenis berita terbaru dan jenis berita popular yang dipilih berdasarkan banyaknya jumlah viewers, seperti yang dapat dilihat pada Error! Reference source not found.

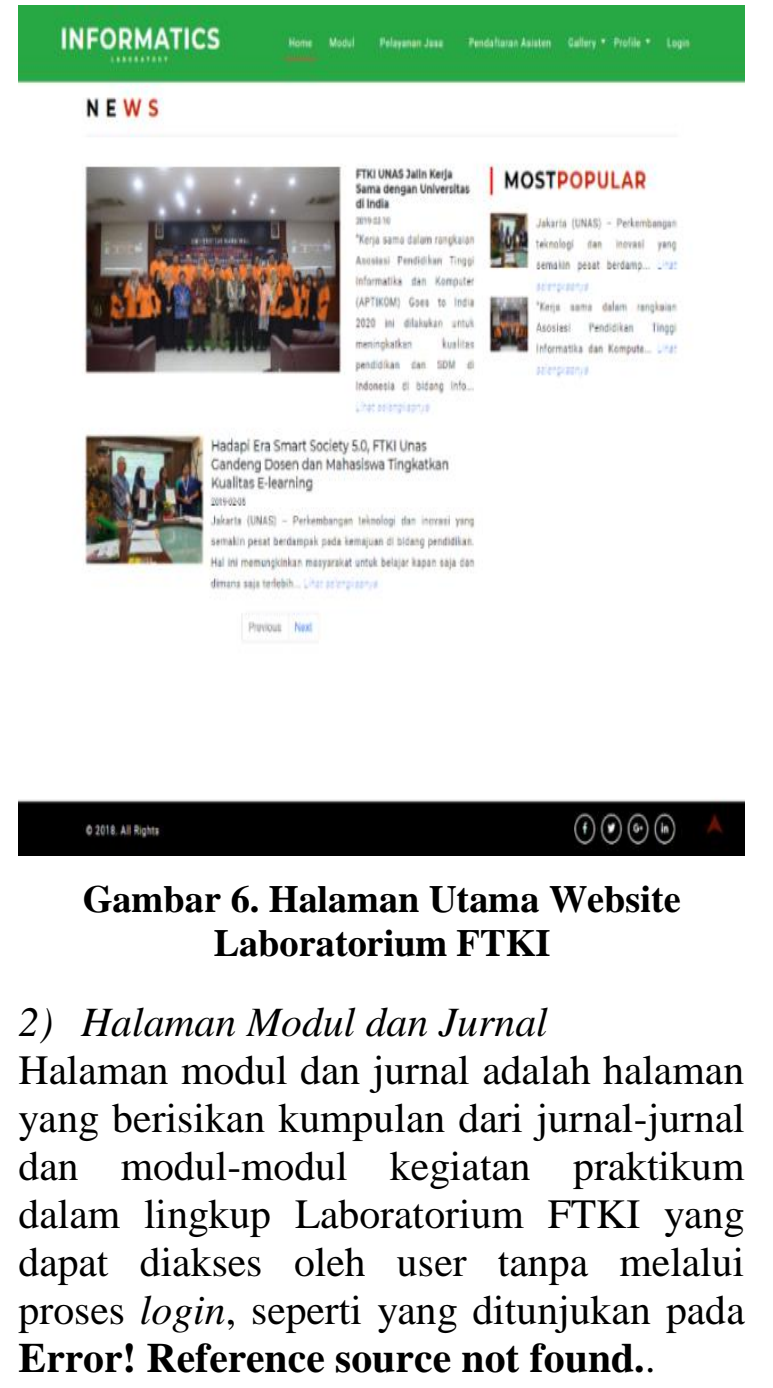

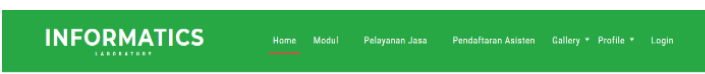

JURNAL DAN MODUL

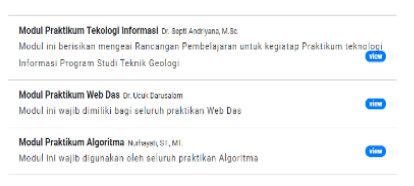

O2018. All High

(†)(-) (1)

Gambar 7. Halaman Jurnal dan Modul

\section{3) Halaman Pelayanan Jasa Publik}

Halaman pelayanan jasa publik berisikan form permohonan pelayanan jasa publik dari user kepada pihak laboratorium dengan mengisikan data diri seperti nama, no telepon, email, dan isi dari permohonan tersebut, yang selanjutnya akan di proses melalui email yang terdaftar oleh admini laboratorium jika permohonan pelayanan jasa tersebut disetujui. Adapun jenis pelayanan jasa yang di tawarkan oleh pihak laboratorium diantaranya adalah: Peminjaman alat dan pengolahan data, seperti yang di tunjukan oleh Error! Reference source not found.

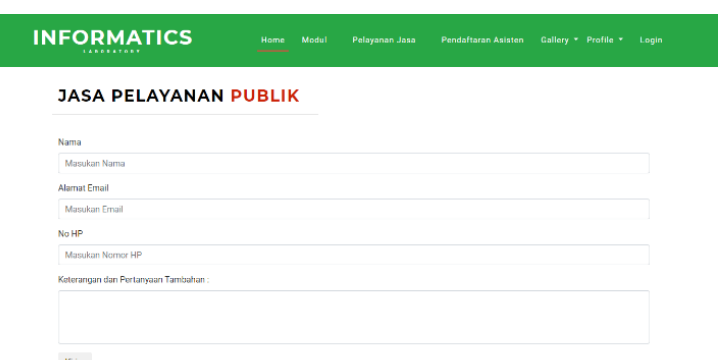

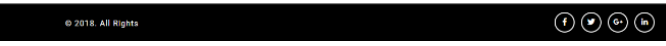

Gambar 8. Halaman Jasa Publik

\section{4) Halaman Pendaftaran Asisten}

Halaman pendaftaran adalah halaman utama dalam pembuatan sistem ini, digunakan sebagai bahan inputan untuk proses pengambilan keputusan pemilihan asisten laboratorium [12]. Pada halaman ini setiap calon yang mendaftarkan untuk menjadi asisten harus melampirkan 
beberapa berkas persyaratan yang telah ditetapkan dan mengisi beberapa data diri yang harus dilengkapi, seperti yang dijelaskan pada Error! Reference source not found.

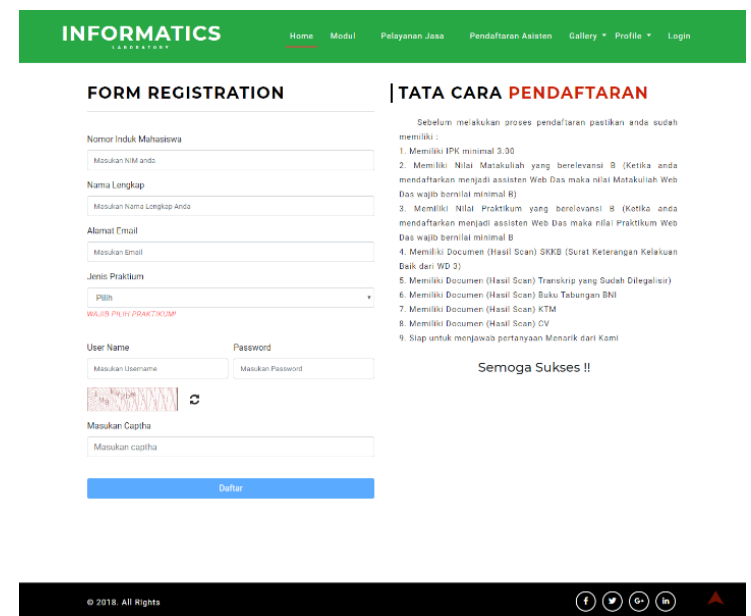

Gambar 9. Halaman Pendaftaran Asisten

\section{5) Halaman Gallery}

Halaman gallery merupakan halaman yang berisikan data dokumentasi kegiatan kegiatan yang dilaksanakan dalam lingkungan Laboratorium FTKI yang dibedakan berdasarkan jenis laboratorium, seperti yang digambarkan pada Error! Reference source not found.

\section{INFORMATICS}

GALLERY OF

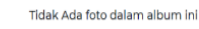

oma angom

(1) $(\odot)(-)$

Gambar 10. Halaman Gallery

\section{Pengujian Sistem}

Tabel 1. Pengujian Sistem Terhadap Interface Website

\begin{tabular}{clc}
\hline No & \multicolumn{1}{c}{ Interface } & Keterangan \\
\hline 1 & Homepage & Berhasil \\
2 & Form Registration & Berhasil \\
3 & Gallery & Berhasil \\
4 & Jasa Pelayanan Publik & Berhasil \\
5 & Jurnal dan Modul & Berhasil \\
\hline
\end{tabular}

Dari hasil pengujian sistem terhadap interface yang dirancang telah didapat keberhasilan $100 \%$, dimana setiap interface yang diuji telah berfungsi sesuai dengan sebagaimana desain website dibuat.

\section{SIMPULAN}

Dari hasil pengujian telah didapat keberhasilan $100 \%$ dari sisi interface dan setelah melakukan analisa dan perancangan sistem penunjang keputusan pemilihan asisten Laboratorium FTKI dengan metode Weighted Product dan Weighted Sum Model berbasis website mempermudah dalam melakukan penyeleksian calon asisten secara administratif sehingga proses penentuan asisten lebih cepat dari biasanya dan tersistem.

\section{DAFTAR PUSTAKA}

[1] N. Pakaya and Amiruddin, "Pemuda Nusantara Dengan Menggunakan Metode," Ilk. J. Ilm., vol. 9, no. 3, pp. 331-337, 2017.

[2] H. R. Hatta, M. Rizaldi, and D. M. Khairina, "Penerapan Metode Weighted Product Untuk Pemilihan Lokasi Lahan Baru Pemakaman Muslim Dengan Visualisasi Google Maps," J. Nas. Teknol. dan Sist. Inf., vol. 2, no. 3, pp. 85-94, 2016, doi: 10.25077/teknosi.v2i3.2016.85-94.

[3] E. W. Fridayanthie, N. Khoirurrizky, and T. Santoso, "Sistem Pendukung Keputusan Pemilihan Karyawan Terbaik Menggunakan Metode Weighted Product," Paradig. - J. Komput. dan Inform., vol. 22, no. 1, pp. 41-46, 2020, doi: 10.31294/p.v21i2.6418.

[4] Mesran, Suginam, S. D. Nasution, and A. P. Utama, "Penerapan Weighted Sum Model (WSM) Dalam Penentuan Peserta Jaminan 
Kesehatan Masyarakat," Jurasik (Jurnal Ris. Sist. Inf. dan Tek. Inform., vol. 2, no. 1, p. 40, 2017, doi: 10.30645/jurasik.v2i1.17.

[5] Solikhun, "Perbandingan Metode Weighted Product Dan Weighted Sum Model Dalam Pemilihan Perguruan Swasta Terbaik Jurusan Komputer," Kumpul. J. Ilmu Komput., vol. 04, no. 01, pp. 70-87, 2017.

[6] D. M. Khairina, D. Ivando, and S. Maharani, "Implementasi Metode Weighted Product Untuk Aplikasi Pemilihan Smartphone Android," J. INFOTEL - Inform. Telekomun. Elektron., vol. 8, no. 1, p. 16, 2016, doi: 10.20895/infotel.v8i1.47.

[7] S. Maharani, S. Hermawati, I. F. Astuti, and M. Khairina, "Pemilihan Taman Kanak-kanak Menggunakan Metode Weighted Product di Kecamatan Sungai Kunjang Samarinda," J. Teknol. Inf. dan Ilmu Komput., vol. 5, no. 4, p. 465, 2018, doi: 10.25126/jtiik.201854814.

[8] J. E. M, D. Andreswari, and K. Anggriani, "Pemilihan Jenis Kayu Untuk Mebel Dengan Metode Weighted Product (WP) \& Technique for Order Preference By Similarity To Ideal Solution (TOPSIS)," $J$. Rekursif, vol. 4, no. 3, pp. 301-310, 2016.
[9] M. Fauzi, "Penerapan Metode Weight Product Untuk Sistem Pendukung Keputusan Pemilihan Pemasok Alat Musik Pada Studio Musik Enterprise," J. Tek. Inform. Kaputama, vol. 2, no. 1, pp. 98-104, 2018.

[10] B. Sinaga, Sulindawaty, and I. Siagian, "Sistem Pendukung Keputusan Pemilihan Asuransi Dengan Metode Weighted Product Dan Weighted Sum Model Pada PT. Prudential," J. Mantik Penusa, vol. 1, no. 2, pp. 59-64, 2017, [Online]. Available: http://ejurnal.pelitanusantara.ac.id/index.php /mantik/article/view/267/166.

[11] D. C. Yoni and H. Mustafidah, "Penerapan Metode WP (Weighted Product) Untuk Pemilihan Mahasiswa Lulusan Terbaik di Fakultas Teknik Universitas Muhammadiyah Purwokerto," Juita, vol. IV, no. 1, pp. 22-27, 2016, [Online]. Available: http://jurnalnasional.ump.ac.id/index. php/JUITA/article/view/1184.

[12] P. Utomo and A. Budiman, "Sistem Pendukung Keputusan Pemilihan Mahasiswa Penerima Beasiswa Lokal Manajemen Informatika Unmer Madiun menggunakan Weighted Product," Res. Comput. Inf. Syst. Technol. Manag., vol. 2, no. 1, p. 1, 2019 , doi: 